\title{
Screening for Hydrocarbon Degrading Bacteria Using Redox Indicator 2, 6-Dichlorophenol Indophenol
}

\author{
James Iniobong Ime, Ibuot Aniefon Alphonsus, Akpan Patience Saturday, Ben Mayen Godwin, \\ Etuk Christiana Utibe, Umoren Emmanuel Anthony
}

Department of Science Technology, Akwa Ibom State Polytechnic, Ikot Osurua, Ikot Ekpene, Nigeria

\section{Email address:}

anialphonsus@yahoo.com (A. A. Ibuot)

\section{To cite this article:}

James Iniobong Ime, Ibuot Aniefon Alphonsus, Akpan Patience Saturday, Ben Mayen Godwin, Etuk Christiana Utibe, Umoren Emmanuel Anthony. Screening for Hydrocarbon Degrading Bacteria Using Redox Indicator 2, 6-Dichlorophenol Indophenol. Chemical and Biomolecular Engineering. Vol. 3, No. 2, 2018, pp. 11-16. doi: 10.11648/j.cbe.20180302.11

Received: August 2, 2018; Accepted: September 7, 2018; Published: October 13, 2018

\begin{abstract}
Contamination by petroleum products and its derivatives promotes serious environmental damage. Biodegradation capacity studies are important when deciding the correct bioremediation strategy to employ. The use of redox indicator 2, 6Dichlorophenol Indophenol (DCPIP) is a rapid, simple and low cost model for evaluating capability of microorganisms to utilize and/or degrade petroleum hydrocarbons. This study involved isolation and screening of bacterial species capable of utilizing hydrocarbons from soil at two auto-mechanic workshops in Uyo, Akwa Ibom State. Results of the physicochemical analysis of the soil samples showed higher levels of properties (Moisture content, Organic Carbon content, Total Hydrocarbon Content) in the polluted soil samples when compared with unpolluted (control) soil sample. Total heterotrophic bacterial populations in polluted soil samples ranged between $4.4 \pm 1.90 \times 10^{7}$ and $6.0 \pm 32.0 \times 10^{7} \mathrm{CFU} / \mathrm{g}$ while hydrocarbon utilizing bacterial counts were between $3.2 \pm 0.05 \times 10^{7}$ and $5.2 \pm 25.2 \times 10^{7} \mathrm{CFU} / \mathrm{g}$. Eight bacteria species capable of utilizing petroleum were isolated from these soils by enrichment technique. Isolated bacteria include: Corynebacterium spp, Pseudomonas aeruginosa, Micrococcus agilis, Flavobacterium aquatile, Staphylococcus aureus, Micrococcus luteus, Serratia odorifera and Bacillus substilis. Screening of bacterial isolates for efficiency in hydrocarbon utilization using DCPIP, measured by using colorimetry, revealed Bacillus substilis, Pseudomonas aeruginosa, Micrococccus agilis, Flavobacterium aquatile Micrococcus luteus and Corynebacterium spp to be able to rapidly utilize hydrocarbons from waste engine oil.
\end{abstract}

Keywords: Hydrocarbon, Bacteria, 2, 6-Dichlorophenol Indophenols

\section{Introduction}

Releases of persistent, bioaccumulative and toxic chemicals have a detrimental impact on human health and the environment. Petroleum hydrocarbon is one common example of chemicals [1]. The discharge of petroleum products into the environment from drilling, refinement, transportation, storage or distribution processes, accidentally or from sabotage and disruptive actions constitute one of the largest sources of environmental hazards [2].

Contamination of soil by petroleum hydrocarbons also stimulates indigenous microbial populations, which are capable of utilizing the petroleum hydrocarbons as their carbon and energy source thereby degrading the contaminants. The ability to degrade hydrocarbon substrates is exhibited by a wide variety of bacteria genera [3]. The most important (based on frequency of isolation) genera of hydrocarbon utilizers are Pseudomonas, Achromobacter, Arthrobacter, Micrococcus, Nocardia, Vibrio, Acinetobacter, Brevibacterium, Corynebacterium, Flavobacterium, Candida, Rhodotorula, and Sporobolomyces [4], Streptococcus sp., Escherichia coli, Staphylococcus sp., Klebsiella sp., Bacillus sp., Mycobacterium sp., Enterobacter aerogenes, Salmonella sp., and Micrococcus sp [5]. A wide variety of literature on the mechanisms of microbial breakdown of petroleum hydrocarbons exist [3, 1, 6, 7].

To demonstrate that microorganisms are potentially useful for bioremediation, it is important to demonstrate the ability 
of such microbes to utilize and/or biodegrade the hydrocarbon under controlled conditions. For practical reasons this cannot be easily accomplished in situ and thus must be accomplished in laboratory feasibility studies. The goal of a laboratory feasibility study is to identify biodegradative ability, limiting factors and recommend ways to mitigate these before application in the field [8].

A number of techniques have evolved for screening of hydrocarbon degrading microorganisms. These include use of liquid medium with hydrocarbons [9], oil-containing mineral agar plates [30], measurement of turbidity in microtiter plates, oxygen consumption, most probable techniques and sheen screen technique [10]. However, all these methods are either laborious, time consuming, expensive or not reliable [11].

2, 6-Dichlorophenol Indophenol (DCPIP) as originally used and reported by Vernon and Zaugg, [12] is a qualitative and quantitative redox indicator. Its principle is based on oxidation of carbon source in which electrons are transferred to electron acceptors such as oxygen, nitrate and sulfate [13]. By incorporating an electron acceptor such as DCPIP to the culture medium, it is possible to ascertain the ability of the microorganism to utilize the substrate by observing the color change of DCPIP from blue (oxidized) to colorless (reduced). The strains, which decolorize the DCPIP in the quickest time, are chosen as the best oil degraders. The absorbance values in $600 \mathrm{~nm}$ could also be used to precisely collect data regarding the biodegradation process through time. The colorimetric screening technology was first reported to be applied in oil biodegradation by Hanson et al. [14]. The DCPIP technique is a rapid, simple and low cost procedure for evaluating capability of different microorganisms to degrade different oil [15], and has been successfully employed in several studies $[16,17]$.

This study surveyed physicochemical parameter and bacteria present in hydrocarbon contaminated soil and determined qualitatively and quantitatively the utilization of hydrocarbons by these isolates growing in waste engine oilsupplemented medium.

\section{Materials and Methods}

\subsection{Sample Collection}

Composite waste engine oil-contaminated soil samples were collected from two mechanic workshops in Uyo, Akwa Ibom State. Samples were taken at the depth of 10-20 cm using surface sterilized soil auger. Unpolluted soil samples (control samples) were collected from unpolluted zones of the same environment.

\subsection{Microbiological and Physicochemical Analysis of Samples}

Microbiological analysis of samples was done using the method of Cheesbrough, [18] and Holt et al., [19]. Physicochemical analysis of samples was done using the method of AOAC [20].

\section{Results}

The results of the physicochemical analysis of the soil samples as shown in Table revealed higher levels of properties in the polluted soil samples when compared with the unpolluted soil sample. Soil $\mathrm{pH}$ was $6.79 \pm 0.24$ in unpolluted soil, 5.98 \pm 0.13 in MW1 and 5.78 \pm 0.03 in MW2. Moisture content was $32.25 \pm 9.30$ in unpolluted soil, $43.09 \pm 0.65$ in MW1 and 45.13 \pm 7.02 in MW2. Organic carbon content was $3.7 \pm 2.43$ in unpolluted soil, $5.32 \pm 2.65$ in MW1 and 9.79 \pm 0.51 in MW2. THC was $39.97 \pm 13.49$ in unpolluted soil, 2933.76 \pm 404.27 in MW1 and $3202.61 \pm 675.07$ in MW2. Total heterotrophic bacterial count of soil samples ranged from $1.9 \pm 2.00 \times 10^{6}$ for the control soil, $4.4 \pm 1.90 \times 10^{7}$ to $6.0 \pm 3.20 \times 10^{7}$ for impacted soil The HUB ranged from $6.5 \pm 0.04 \times 10^{5}$ in control soil, $3.2 \pm 0.05 \times 10^{7}$ and $5.2 \pm 2.52 \times 10^{7}$ in impacted soils (Table 2). Eight bacterial isolates were obtained from the impacted soil samples. They include: Corynebacterium spp, Pseudomonas aeruginosa, Micrococcus agilis, Flavobacterium aquatile, Staphylococcus aureus, Micrococcus luteus, Serratia odorifera and Bacillus substilis. Corynebacterium spp, Bacillus substilis, Pseudomonas aeruginosa, Micrococccus agilis, and Micrococcus luteus had high utilization of hydrocarbons as revealed by their absorbance within 120 hours of incubation (Figure 2). Bacillus substilis showed the highest utilization ability; absorbance readings were not determinable after 96 hours of incubation at $600 \mathrm{~nm}$. The DCPIP indicator was also rapidly decolorized in cultures containing these isolates 72 hours of incubation (Figure 1). DCPIP indicator was not decolorized within culture containing Flavobacterium aquatile and Serratia odorifera. Decolourization only occurred in cultures of Staphylococcus aureus after 96 hours incubation.

Table 1. Physicochemical parameters of soil sample.

\begin{tabular}{llll}
\hline \multirow{2}{*}{ Parameter } & Unpolluted & Polluted & MW2 \\
\cline { 3 - 4 } & & MW1 & $5.78 \pm 0.03$ \\
$\mathrm{pH}$ & $6.79 \pm 0.24$ & $5.98 \pm 0.13$ & $45.13 \pm 7.02$ \\
Moisture content (\%) & $32.25 \pm 9.30$ & $43.09 \pm 0.65$ & $9.79 \pm 0.51$ \\
Organic carbon content (\%) & $3.7 \pm 2.43$ & $5.32 \pm 2.65$ & $3202.61 \pm 675.07$ \\
THC (mg/kg) & $39.97 \pm 13.49$ & $2933.76 \pm 404 . .27$ & 3 \\
\hline
\end{tabular}

Key: MW1-Mechanic workshop 1

MW2-Mechanic workshop 2 
Table 2. Total bacterial counts of soil samples.

\begin{tabular}{llll}
\hline \multirow{2}{*}{ Bacterial count } & Unpolluted & Polluted & MW2 \\
\cline { 2 - 4 } & & MW1 & $6.0 \pm 3.20 \times 10^{7}$ \\
THB (CFU/g) & $1.9 \pm 2.00 \times 10^{6}$ & $4.4 \pm 1.90 \times 10^{7}$ & $5.2 \pm 2.52 \times 10^{7}$ \\
HUB (CFU/g) & $6.5 \pm 0.04 \times 10^{5}$ & $3.2 \pm 0.05 \times 10^{7}$ & \\
\hline
\end{tabular}

Key: MW1-Mechanic workshop 1

MW2-Mechanic workshop 2

Table 3. Morphological and biochemical characteristics of bacterial isolates from soil samples.

\begin{tabular}{|c|c|c|c|c|c|c|c|c|c|}
\hline Isolate number & Cell shape & Gram stain & Spore & Catalase & Motility & Oxidase & Litmus reaction & Urease & Gelatin \\
\hline MW1e, MW2d, MW3d & Chain rods & + & + & + & + & + & + & - & + \\
\hline MW1g & Rods & - & - & + & + & - & - & + & + \\
\hline MW1b, MW2a, MW3c & Rods & - & - & + & + & - & - & - & + \\
\hline MW1a & Short rods & + & - & + & - & - & - & - & - \\
\hline MW3b, MW1c & Cocci & + & & + & & + & - & + & - \\
\hline MW1d & Short rods & - & - & + & - & + & + & - & - \\
\hline MW3a, MW2b & Cocci & + & - & + & + & - & + & - & - \\
\hline
\end{tabular}

Table 3. Continued.

\begin{tabular}{|c|c|c|c|c|c|c|c|c|}
\hline Isolate number & Citrate & Glucose & Maltose & Manitol & Lactose & Sucrose & Arabinose & Probable Organism \\
\hline MW1e, MW2d, MW3d & + & $\mathrm{AO}$ & $\mathrm{AO}$ & $\mathrm{AO}$ & - & $\mathrm{AO}$ & $\mathrm{AO}$ & Bacillus substillis \\
\hline MW1g & + & $\mathrm{AO}$ & $\mathrm{AO}$ & $\mathrm{AO}$ & $\mathrm{AO}$ & $\mathrm{AO}$ & $\mathrm{AO}$ & Serratia odorifera \\
\hline MW1b, MW2a, MW3c & - & - & $\mathrm{AO}$ & $\mathrm{AO}$ & $\mathrm{AO}$ & - & $\mathrm{AO}$ & Pseudomonas aeruginosa \\
\hline MW3b, MW1c & - & $\mathrm{AO}$ & - & $\mathrm{AO}$ & - & - & $\mathrm{AG}$ & Micrococcus agilis \\
\hline MW1d & - & $\mathrm{AO}$ & $\mathrm{AO}$ & - & $\mathrm{AO}$ & $\mathrm{AO}$ & - & Flavobacterium Aquatile \\
\hline MW3a, MW2b & - & - & - & - & - & $\mathrm{AO}$ & - & Staphylococcus aureus \\
\hline
\end{tabular}

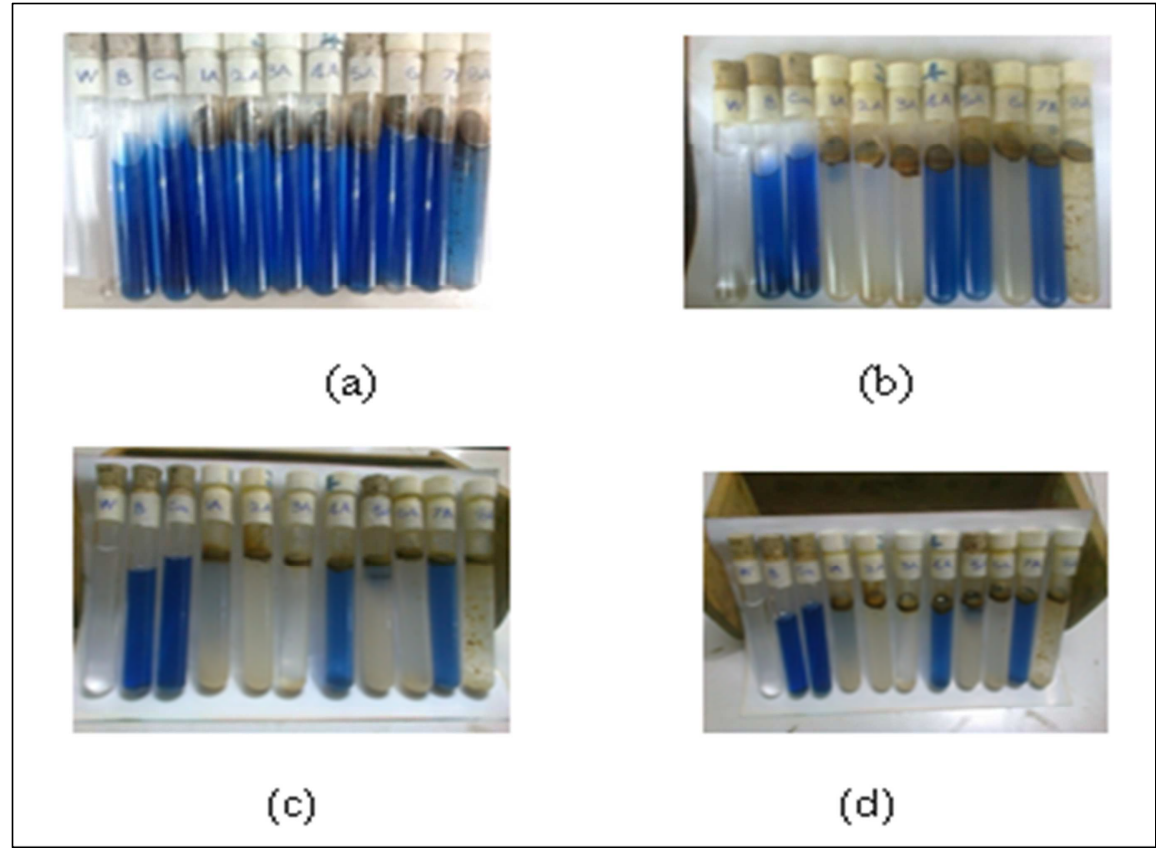

Figure 1. (a-d): colorimetric screening of bacterial isolates for hydrocarbon utilization with DCPIP indicator, after incubation at (a) 48 hours, (b) 72 hours, (c) 96 hours and (d) 120 hours

Keys: $\mathrm{W}=$ Water only; $\mathrm{B}=\mathrm{DCPIP}$ blank $\mathrm{CO}=\mathrm{DCPIP}+\mathrm{MSM}$ only

$1 \mathrm{~A}=$ Corynebacterium sp; $2 \mathrm{~A}=$ Pseudomonas aeruginosa; $3 \mathrm{~A}=$ Micrococcus agilis; $4 \mathrm{~A}=$ Flavobacterium aquatile; $5 \mathrm{~A}=$ Staphylococcus aureus; $6 \mathrm{~A}$ $=$ Micrococcus luteus; $7 \mathrm{~A}=$ Serratia odorifera; $8 \mathrm{~A}=$ Bacillus substilis 


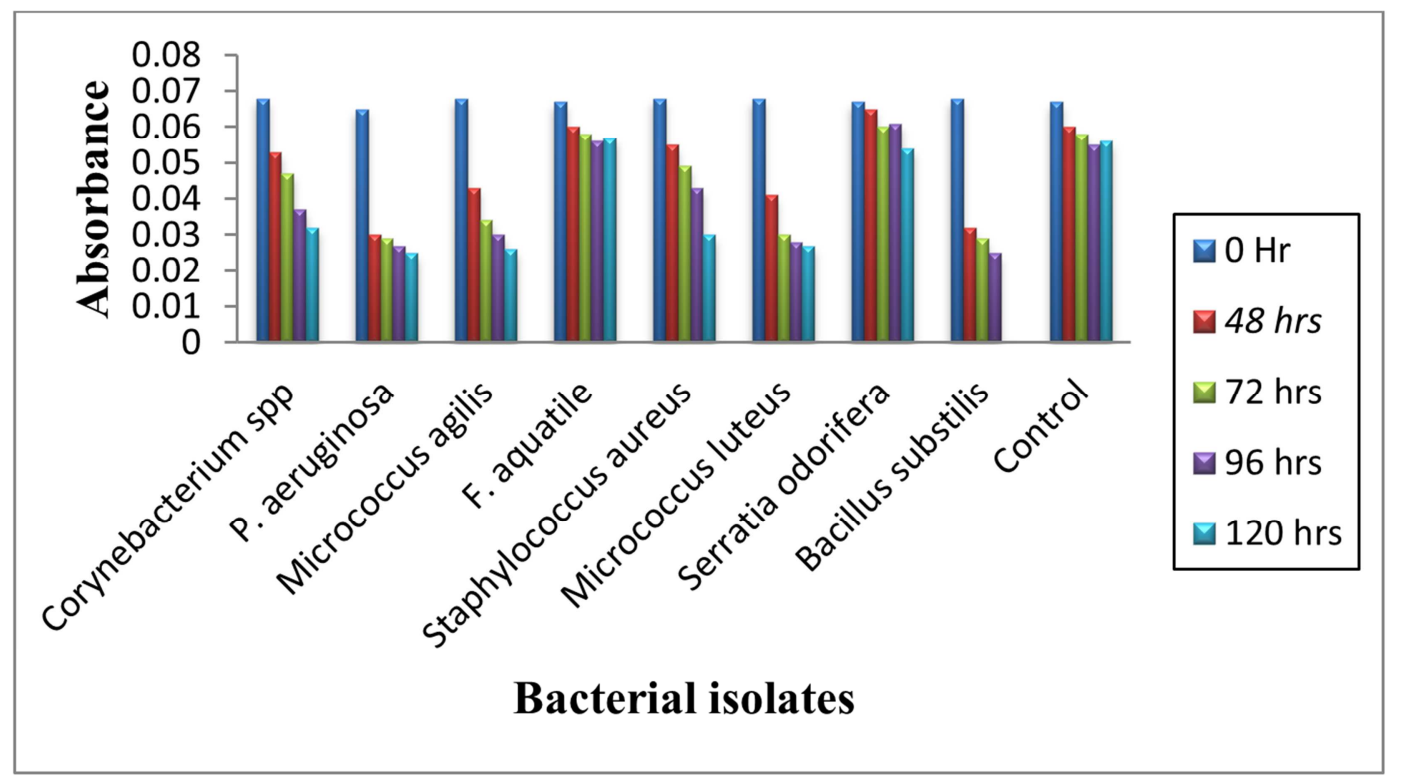

Figure 2. Absorbance $\left(O D_{600}\right)$ of bacterial growth in hydrocarbon.

\section{Discussion}

The results of the physicochemical analysis of the soil samples as shown in Table 1 revealed higher levels of properties in the polluted soil samples when compared with the unpolluted soil sample. The results agrees the results of Chikere, [21] and Chikere and Ekwuabu, [22] which reported high physicochemical parameters in polluted soil samples compared to unpolluted samples determined and indicated previous exposure of the polluted samples to hydrocarbon contamination with traces of other organic and inorganic contaminants. The parameters determined indicated that the samples had been exposed to hydrocarbon contamination [23, 21]. The contamination may have resulted in the low $\mathrm{pH}$ of $5.98 \pm 0.13$ for MW1 and $5.78 \pm 0.03$ observed in polluted soils as compared to $6.79 \pm 0.24$ in the pristine (control) soil which is neutral to slightly alkaline. Previous studies have demonstrated that the $\mathrm{pH}$ range optimal for biodegradation of hydrocarbons is 6-7 [24, 25].

Determination of the total bacterial populations of the oilpolluted soil shows that a significant proportion of the total heterotrophic bacterial populations are hydrocarbon utilisers. The high bacterial counts recorded in polluted soil samples $4.4 \pm 1.90 \times 10^{7}$ in MW1 and $6.0 \pm 3.20 \times 10^{7}$ in MW2 compared with $1.9 \pm 2.00 \times 10^{7}$ in the unpolluted control samples could be attributed to the myriad of nutrients, high organic matter concentration and other ecological factors that influence the survival of soil microorganisms that play important roles in the decomposition and recycling of nutrients [26].

The difference between THB and HUB counts was observed to be insignificant suggesting that most of the micro-organisms present in the various polluted sample sites are hydrocarbonoclastic. Continuous input of petroleumbased pollutants usually results in an enriched microbial community capable of surviving toxic contamination [22].

Isolation and screening of microorganisms for their efficiency in utilization of hydrocarbons before field trials is important in bioremediation process. A total of seven bacterial genera; Bacillus, Pseudomonas, Micrococcus, Serratia, Staphylococcus, Flavobacterium, Corynebacterium and as presented in Table 3 were isolated from polluted soil. The prevalence of most of these isolates; Flavobacterium, Enterobacter, Norcardia and Acinetobacter [27], Micrococcus, Bacillus, Corynebacterium, Vibrio, Pseudomonas and Flavobacterium [28], Serratia, Pseudomonas, Proteus, Klebsiella, Microccocus and Staphylococcus [29] in hydrocarbon polluted has been reported. These isolates have also been demonstrated by other researchers to be hydrocarbon degraders [30, 31].

To ascertain microbial ability to utilize hydrocarbon substrates by simply observing the color change of DCPIP, in which the quickest decolorization time represents the best oil degradation, is a major breakthrough in biodegradation studies. Bacillus substilis, Serratia odorifera, Pseudomonas aeruginosa, Micrococccus agilis, Flavobacterium aquatile and Micrococcus luteus and were able to utilize hydrocarbons in waste engine oil as shown by change in the colour of the DCPIP indicator over time. This is due to reduction of the indicator by oxidized products of hydrocarbon degradation which supports the facts that the isolates are potential hydrocarbon oxidizers [32]. Bacillus and Pseudomonas species have been reported to be among the most frequently isolated bacteria from hydrocarbonpolluted sites [33, 34]. The oxidation of DCPIP supports the facts that the isolates were potential hydrocarbon degraders [16].

The control assays ( $\mathrm{C} 0$ and $\mathrm{C} 1)$ maintained the blue color, although with slight reductions in absorbance readings Absorbance at a wavelength of $600 \mathrm{~nm}$ was monitored for the organisms because a peak in absorbance was observed at 600 $\mathrm{nm}$ as reported by Yoshida et al. [35].

Based on rapid decolourisation and absorbance readings, 
Bacillus substilis was observed to be the most active hydrocarbon utilizer. This agrees with previous observations identifying the Bacillus genus as an efficient hydrocarbon degrading microorganism [36, 37]. This suggests high adaptability within this environment with potential for application in hydrocarbon degradation.

\section{Conclusion}

This study reveals a quantitative and qualitative approach towards the determination of potentials of hydrocarbonoclastic bacteria, as well as giving a measureable ability of these groups of bacteria for possible use in hydrocarbon impacted soil remediation. Using the Redox indicator 2, 6- dichlorophenol indophenols approach of determination of potential hydrocarnoclastic bacteria proofs to be a better technique and this approach is therefore recommended for determination of potential hydrocarbonoclastic bacteria.

\section{References}

[1] Atlas, R. M. (1995). Bioremediation of petroleum pollutants. International Biodeterioration and Biodegradation, 35 (13):317-327

[2] Kadafa, A. A. (2012). Oil Exploration and Spillage in the Niger Delta of Nigeria. Civil and Environmental Research, 2 (3):38-51.

[3] Atlas, R. M. (1981). Microbial degradation of petroleum hydrocarbons: an environmental perspective. Microbiological Reviews, 45 (1):180-209.

[4] Bartha, R., and Atlas. R. M. (1977). The microbiology of aquatic oil spills. Advances in Applied Microbiology, 22:225266.

[5] Makut, M. D. and Ishaya, P. (2010). Bacterial species associated with soils contaminated with used petroleum products in Keffi town, Nigeria. African Journal of Microbiology Research, 4 (16):1698-1702.

[6] Bamforth, S. M. and Singleton, I. (2005). Bioremediation of polycyclic aromatic hydrocarbons: current knowledge and future directions. Journal of Chemical Technology and Biotechnology, 80:723-736.

[7] Vidali, M. (2001). Bioremediation: an overview. Pure and Applied Chemistry, 73: 1163-1172.

[8] Balba, M. T., Al-Awadhi, N. and Al-Daher, R. (1998). Bioremediation of oil- contaminated soil: microbiological methods for feasibility assessment and field evaluation. Journal of Microbiological Methods, 32:155-164.

[9] Malatova, K. (2005). A thesis submitted in partial fulfillment of the requirement for the Degree of Master of Science in Chemistry. Department of Chemistry, Rochester Institute of Technology, Rochester, NY.

[10] Okpokwasili, G. C. and Amanchukwu, S. C. (1989). Hydrocarbon degradation and utilization by palm wine isolates. FEMS Microbiology Letters, 57:151-154.
[11] Desai, A. and Vyas P. (2006). Petroleum and hydrocarbon microbiology, Department of Microbiology, M. S. University of Baroda, Vadodara, $\mathrm{Pp}, \quad$ 1-22. http://nsdl.niscair.res.in/jspui/bitstream .

[12] Vernon, L. P. and Zaugg, W. S. (1960). Photoreductions by fresh and aged chloroplasts; requirement for ascorbate and 2, 6-dichlorophenolindophenol with aged chloroplasts. Journal of Biological Chemistry, 235:2728-2733.

[13] Bidoia E. D., Montagnolli R. N. and Lopes P. R. M. (2010), Microbial biodegradation potential of hydrocarbons evaluated by colorimetric technique: a case study, In: Current Research, Technology and Education Topics in Applied Microbiology and Microbial Biotechnology, Mendez-Vilas A. (Ed.), FORMATEX, Badajoz, Spain.

[14] Hanson, K. G., Desai, J. D. and Desai, A. J. (1993). A rapid and simple screening technique for potential crude oil degrading microorganisms. Biotechnology Techniques, 7:745748.

[15] Mariano, A. P., Bonotto, D. M., Angelis, D. F., Pirollo, M. P. S. and Contiero, J. (2008), Biodegradability of commercial and weathered diesel oils. Brazilian Journal of Microbiology, 39:33-142.

[16] Patil, T. D., Pawar, S., Kamble, P. N. and Thakare, S. V. (2012), Bioremediation of complex hydrocarbons using microbial consortium isolated from diesel oil polluted soil. Der Chemica Sinica, 3:953-958.

[17] Balogun, S. A., Shofola, T. C., Okedeji, A. O. and Ayangbenro, A. S. (2015). Screening of hydrocarbonoclastic bacteria using redox indicator 2, 6-dichlorophenol indophenol. Global Nest Jour., 17: 1-9.

[18] Cheesbrough, M. (2006). District Laboratory Practice in Tropical Countries (Part 2) Cambridge University Press. Hon Kong. Pp 64-70.

[19] Holt, J. G., Krieg, N. R., Sneath, P. H. A., Stanley, J. T., William, S. T. (1994). Bergey's Manual of Determinative Bacteriology. $9^{\text {th }}$ edition. William and Wilkins, Baltimore.

[20] AOAC (2003). Official methods of analysis of the Association of Official analytical chemist, 17th Edition. Association of Official analytical chemist, Arlington, Virginia. Pp. 96-105.

[21] Chikere, C. B. (2012). Culture-Independent analysis of bacterial community composition during bioremediation of crude oil-polluted soil. British Microbiology Resources Journal, 2 (3):187-211.

[22] Chikere, C. B. and Ekwuabu, C. B. (2014). Cultureindependent characterization of hydrocarbon utilizing bacteria in selected crude oil-impacted sites in Bodo, Ogoniland. African Journal of Environmental Science and Technology, 8 (6): 401-406.

[23] Chikere, C. B. (2010). Bacterial diversity and community dynamics during the bioremediation of crude oil-polluted soil. Dissertation. Microbiology Department. University of Port Harcourt.

[24] Eweis, J. B., Ergas, S. J., Chang, D. P. Y. and Schroeder, E. D. (1998). Bioremediation principles. McGraw-Hill Companies. Inc., New York. Pp. 296. 
[25] Aparna, C., Saitha, P., Himabindu, V., Alok, B. and Anjaneyulu, Y. (2010). Evaluation of bioremediation effectiveness on sediments contaminated with industrial wastes. International Journal Environmental Science, 1 (4): 607-620.

[26] Eze, V. C. and Okpokwasili, G. C. (2010). Microbial and other related changes in Niger Delta River sediment receiving industrial effluents. Continental Journal of Microbiology, 4:15-24.

[27] Ogunbayo, A. O. Bello, R. A. and Nwagbara, U. (2012). Bioremediation of engine oil contaminated site. Journal of Emerging Trends in Engineering and Applied Sciences, 3 (3): 483-489.

[28] Ibiene, A. A., Orji, F. A. and Orji-Nwosu, E. C. (2011). Microbial populationdynamics in crude oil-polluted soils in the Niger Delta. Nigerian Journal of Agriculture Food Environmental, 7:8-13.

[29] Obire, O. and Nwaubeta, O. (2002). Biodegradation of refined petroleum hydrocarbons in soil. JASEM. 5:43-46.

[30] Sarma, A. and Sarma, H. (2010). Enhanced biodegradation by some microbial isolates supplemented with heavy metals. International Journal of Botany, 6:441-448.

[31] Ebrahimi, M., Sarikkhani, M. R. and Fallah. R. (2012). Assessment of biodegradation efficiency of some isolated bacteria from oil-contaminated sites in solid and liquid media containing oil-compounds. International Resources Journal of Applied and Basic Science, 3 (1):138-147.

[32] Selvakumar, S., Sekar, P., Rajakumar, S. and Ayyasamy, P. M. (2014). Rapid screening of crude oil degrading bacteria isolated from oil contaminated areas. The Scitech Journal, 1:24-27.

[33] Atlas R. M. (1992). Petroleum Microbiology. Academic Press, Baltimore, USA.

[34] Okoh, A. I. and Trejo-Hernandez, M. R. (2006). Remediation of petroleum hydrocarbon polluted systems: exploiting the bioremediation strategies. African Journal of Biotechnology, 5: 2520-2525.

[35] Yoshida, N., Hoashi, J., Morita, T., McNiven, S. J., Nakamura, H. and Karube, I. (2001), Improvement of a mediator-type biochemical oxygen demand sensor for on-site measurement. Journal of Biotechnology, 88: 269-275.

[36] Banat J. M., Makkar, R. S. and Cameotra, S. S. (2000), Potential commercial applications of microbial surfactants. Applied Microbiology and Biotechnology, 53: 495-508.

[37] Saadoun, I. (2002). Isolation and characterization of bacteria from crude petroleum oil contaminated soil and their potential to degrade diesel fuel. Journal of Basic Microbiology, 42:420428. 